\title{
Analysis of heat and mass transfer in the manufacturing process of instant soy milk using a laboratory scale spray dryer
}

\author{
Nely Ana Mufarida ${ }^{*}$, Asroful Abidin $^{2}$ \\ 1,2Prodi Teknik Mesin, Fakultas Teknik, Universitas Muhammadiyah Jember \\ Jl. Karimata No.49 Jember, Jawa Timur, Indonesia \\ *Corresponding author: nelyana@unmuhjember.ac.id
}

\begin{abstract}
The events that occur during the drying include heat and mass transfer processes. So based on this, this research will discuss analysis of heat and mass transfer in the process of making instant soy milk using a laboratory scale spray dryer. The research method used is the experimental method. The research that will be carried out will consist of preliminary research and main research. The purpose of this preliminary study was to determine the drying air temperature, fogging pressure, and the ratio of soy milk powder to water in the solution. The best results from preliminary research are used in the main study. Data processing using technical analysis. The results showed that an increase in the drying air temperature of $80^{\circ} \mathrm{C}$, $85^{\circ} \mathrm{C}, 90^{\circ} \mathrm{C}, 95^{\circ} \mathrm{C}$, and $100^{\circ} \mathrm{C}$ caused a decrease in the need for drying air, namely $27.323 \mathrm{~kg}$ of dry air/hour to $9.840 \mathrm{~kg}$ of dry air/hour, time the drying of the material is shorter, namely 1 hour 10 minutes to 1 hour, the increase in thermal efficiency is $81.9 \%$ to $84.3 \%$, and the increase in product weight coming out of the drying chamber is 3.1 grams to 4.1 grams. The results of the questionnaire showed that the panelists tended to rank taste first (65\%), aroma second $(61.25 \%)$, color third $(47.5 \%)$.
\end{abstract}

Keywords: Heat and Mass Transfer; Instant Soy Milk; Laboratory Scale Spray Dryer

\section{Introduction}

Soy milk is a product from soybeans that is widely known and liked by the public because it is a highly nutritious drink that is beneficial for health, especially because of its protein content. Soybean contains about $35 \%$ protein, even in high yielding varieties, the protein content can reach $40-43 \%$ [1]. In addition, soy milk also contains fat, carbohydrates, calcium, phosphorus, iron, provitamin A, vitamin B complex (except B12), and water [2]. The quality of soy milk protein is about $80 \%$ of cow's milk, but does not contain cholesterol and does not cause allergies, so it is suitable for consumption by people with lactose intolerance [3].

How to make soy milk is much used as a powder rather than direct drinks. Powder material is used as a fresh drink, because the powder itself has a very high nutritional value. The protein content of soybean powder itself is higher than whole milk and skimmed milk. When viewed from protein content alone, the powder itself can also be used as a substitute for milk.

Given the shelf life of soy milk does not last long, the problems that are often faced in processing liquid soy milk are low storage capacity and easy quality degradation. One of the processing alternatives that can extend the shelf life is turning it into instant soy milk through drying. The process is by using spray drying technology in the drying process, so that the soy milk becomes instant soy milk. Apart from that, to facilitate the consumption of processed food products, especially in the form of instant drinks, food processing industries generally use spray drying techniques [4].

The drying process is a method for removing some of the water from material by evaporating the water using heat energy. In general, the advantage of this preservation is that the material becomes durable with a small volume of material 
making it easier to transport. The purpose of drying is to reduce the moisture content of the material to a limit where microorganisms and enzyme activities that can cause spoilage will stop, thus the dried material can have a long shelf life [5].

The events that occur during the drying include heat and mass transfer processes. The process of heat transfer is the process of evaporating water from within the material or the process of changing the form from the liquid to the gas phase due to differences in temperature and pressure at the same time between the material and the surrounding air. This given heat will raise the temperature of the material and cause the water vapor pressure in the material to be higher than the water vapor pressure in the air. As a result, there is a mass transfer of water vapor from the surface of the material to the air. So based on this, this research will discuss "Analysis of Heat and Mass Transfer in the Process of Making Instant Soy Milk Using a Laboratory Scale Spray Dryer".

\section{Literature Review}

\section{Advantages of soy milk over cow's milk}

Unlike cow's milk, soy milk can also be used as a substitute for breast milk for babies who suffer from galactosemia. Soy milk also contains lecithin, vitamin $\mathrm{E}$, and isoflavones which are beneficial for health. The content of soy milk is mostly protein, iron, unsaturated fatty acids, and niacin, but low in fat, carbohydrates, and calcium when compared to milk from cows and breast milk [6]. The comparison of the composition of soy milk and cow's milk can be seen in Table 1. Below [7].

Table 1. Comparison of the Composition of Soy Milk and Cow's Milk

\begin{tabular}{lcc}
\hline Composition & $\begin{array}{c}\text { Soy Milk } \\
(\%)\end{array}$ & $\begin{array}{c}\text { Cow Milk } \\
(\%)\end{array}$ \\
\hline Water & 88,60 & 88,60 \\
\hline Calories & 52,99 & 58,00 \\
\hline Protein & 4,40 & 2,90 \\
\hline Carbohydrate & 3,80 & 4,50 \\
\hline Fat & 2,50 & 0,30 \\
\hline
\end{tabular}

\begin{tabular}{lll}
\hline Vit. B 1 & 0,04 & 0,04 \\
\hline Vit. $B_{2}$ & 0,02 & 0,15 \\
\hline Vit. A & 0,02 & 0,20 \\
\hline
\end{tabular}

\section{Spray Dryer Machine}

A spray Dryer is a unit of equipment for producing flour or powder from liquid materials that are sprayed (to form fine particles) into a space that has been circulated with hot air. In this case, the Spray Dryer can be used for the evaporation of materials that replace the process of cooking materials in the furnace. With this method, the material production process becomes more abundant, economical, efficient and stable. However, to determine the effectiveness of the tool, it is necessary to research and test it first so that the advantages, disadvantages, and feasibility of its use can be seen when compared to the traditional powder manufacturing process [8].

\section{Spray Dryer Mechanism}

The working principle of the spray dryer machine is a drying process that begins with the preparation stage of the fruit or vegetable made of juice first where all the skin and seeds are separated. Then all the water from the fruit/vegetable juice that you want to dry is converted into a liquid with added solvent (if needed) and put into the drying tube after being atomized using an atomizer. The liquid from the material that has been in the form of a mist is then contacted with hot air. This contacting event causes the liquid in the form of a mist to dry and turn into a powder. Furthermore, the separation process between hot steam and powder is carried out using a cyclone or filter. After being separated, the powder is then again lowered in temperature according to production needs.

Each extract powder must be easily wetted and dissolved in water and have the following properties:

a. Wettability, the ability of the extract powder to absorb water, depending on the particle size of the powder and the composition of the powder. 
b. Sinkability, the ability of the extract powder to remain at the bottom when mixed with water, depending on the density of the powder.

c. Dispersibility, the ability of the extract powder to be distributed to water without the formation of lumps.

d. Solubility, The ability of the extract powder to dissolve quickly in water, depends on the physical and chemical properties of the resulting extract powder.

With the expected properties of the extract powder as mentioned above, it is possible to control the drying so that the drying machine produces an extract powder product according to its physical and chemical properties.

\section{Research Methods}

The research was conducted at the Mechanical Engineering Laboratory, University of Muhammadiyah Jember. The ingredients (dissolved) used in the preparation of the solution are imported soybeans, sugar, and salt, and $10 \%$ maltodextrin as a filler.

The first step that is carried out in the manufacture of soy milk is sorting the soybean seeds that are not defective, not attacked by pests, wrinkled, or rotten to produce good soy milk. After that, soaked whole soybean seeds in water with a ratio of soy: water $=1: 3$. This treatment serves to soften the soybean seeds and reduce the unpleasant taste. Soaked soybean seeds are then washed and peeled, then boiled soybeans are carried out to soften the seeds and weaken the activity of the lipoxygenase enzyme. Boiling time is about 30 minutes. The next stage is the process of grinding soybean seeds with a ratio of soybean: water $=1: 3$. The resulting soybean slurry is then filtered to obtain soy milk. Then the soy milk is cooked, but not boiling at $\pm 90 \mathrm{o} \mathrm{C}$, then $10 \%$ maltodextrin is added as a filler. The last step is drying the soy milk using a spray dryer. Then the soy milk powder is packaged using aluminum foil wrappers.
The research was conducted using the following spray dryer design concept:

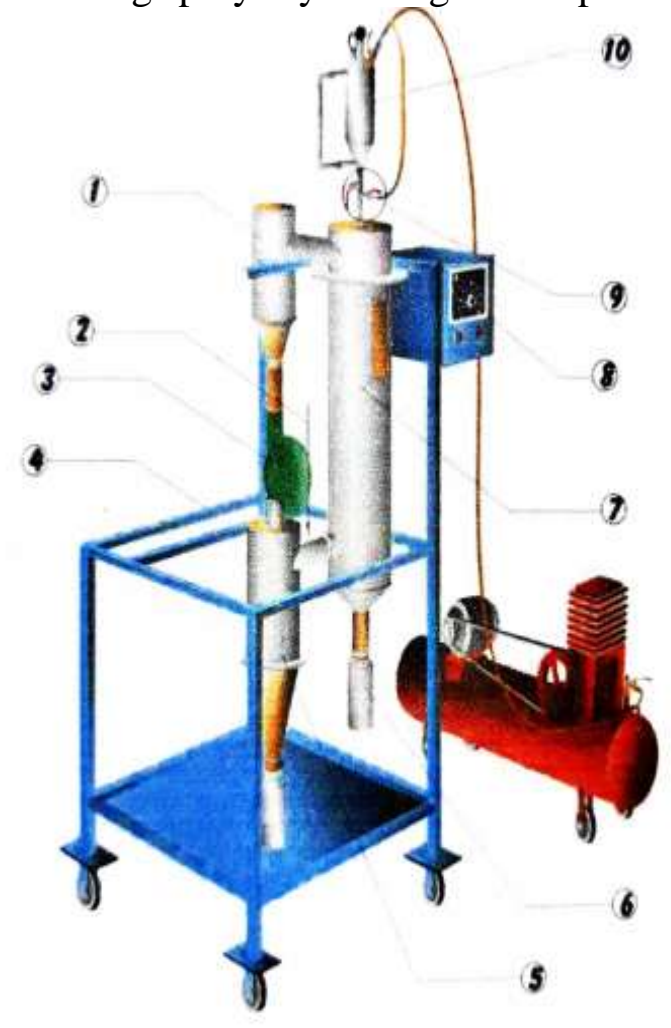

Figure 1. Spray dryer design concept

Details:

1. Heater

2. Mercury thermometer

3. Fan

4. Equipment framework

5. Cyclone separator

6 . The product container bottle

7. Drying room

8. Thermocontrol and switch on heater + fan

9. Nozzle valve and air mixture faucet + material

10. Tank material

\section{Results and Discussions}

The result of the preliminary research is that using drying air temperatures below $80^{\circ} \mathrm{C}$ produces a powder that is sticky to the drying room walls and the separating cyclones or droplets cannot dry completely because the drying air temperature used is too low.

If you use drying air temperatures above $100^{\circ} \mathrm{C}$, it can cause a decrease in 
product quality, that is, the resulting product becomes charred. This is supported by [9].

So based on the foregoing, this study uses five variations of drying air temperature, namely $80^{\circ} \mathrm{C}, 85^{\circ} \mathrm{C}, 90^{\circ} \mathrm{C}$, $95^{\circ} \mathrm{C}$ and $100^{\circ} \mathrm{C}$ which can produce powder with optimal quality and is not sticky to the drying room.

The result of the preliminary research is that using a misting pressure from the compressor below 1.5 bar produces soy milk powder granules that are somewhat coarse and mostly stick to the drying chamber and the separating cyclone so as to reduce the yield produced.

If you use a fogging pressure from the compressor above 2.5 bar, a lot of the soy milk powder produced is carried along with the drying air.

So based on the foregoing, the fogging pressure of the compressor that is suitable for making soy milk powder using a spray dryer is 2 bar, because at that pressure most of the soy milk powder does not come out or disappear with the drying air and is not attached to the drying chamber and cyclone separator.

The result of the preliminary research is soy milk powder and water is 1: 6 , it will increase the viscosity of the liquid so that it clogs the nozzle of the nozzle.

If using a soy milk powder to water ratio of 1: 16, the resulting mixture of soy milk powder and water is too runny because the total solids are low. The low total solids in the material will cause the drying time to be slow, and if the product is too long in contact with high temperatures it will cause color degradation and the yield obtained is also too little.

So based on the above, the appropriate ratio of soy milk powder and water is 1: 11 , because the spray holes on the nozzle are not clogged, the drying process is faster and the total solids produced are more.

Besides being able to preserve food, quick-drying can also increase the fat and protein content in milk [10].

\section{Effect of Drying Air Temperature on Heat and Mass Transfer Process in Making Soy Milk Powder with a Spray Dryer}

The following is a data table and graph of the organoleptic test for drying air temperature including:

a. Graph of the relationship between drying air temperature to drying parameters

b. Graph of the relationship between drying air temperature and drying parameters

c. Graph of the relationship between drying air temperature and drying parameters

Effect of dryer air temperature to drying parameters

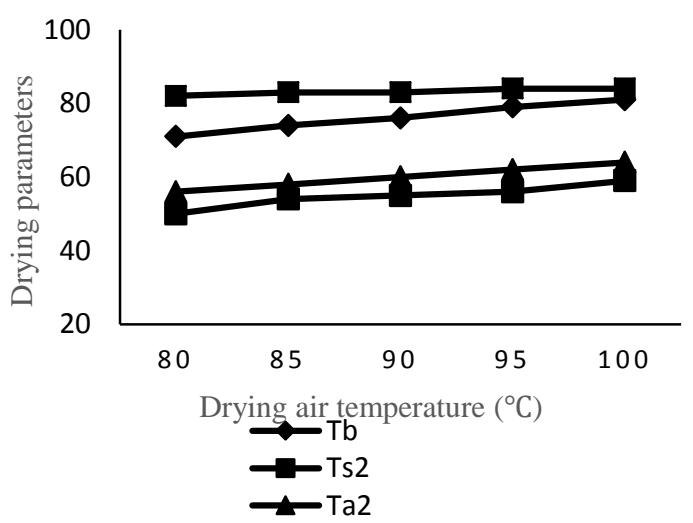

Figure 2. Graph of the relationship between drying air temperature to drying parameters $(\mathrm{Tb}$, Ts2, Ta2 and Thermal Efficiency)

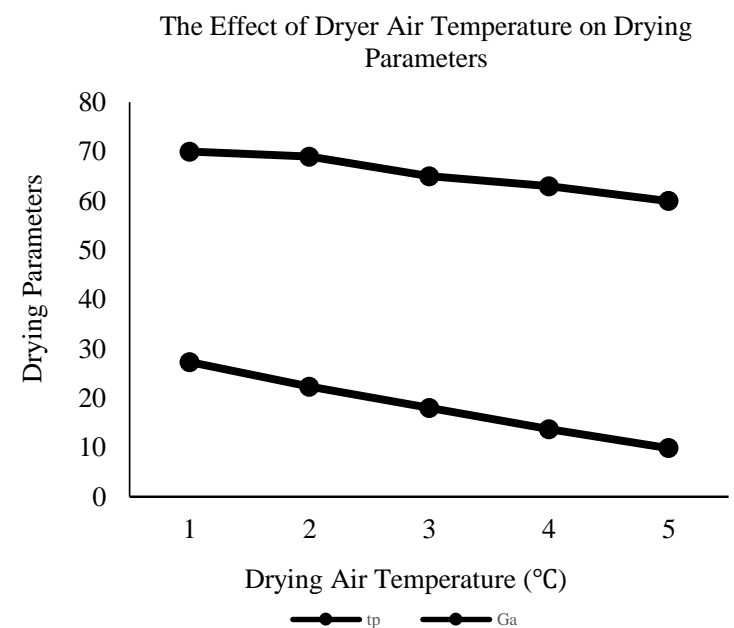

Figure 3. Graph of the relationship between drying air temperature and drying parameters $\left(\mathrm{t}_{\mathrm{p}}\right.$ and $\left.\mathrm{G}_{\mathrm{a}}\right)$ 
Effect of Dryer Temperature to Drying Parameters

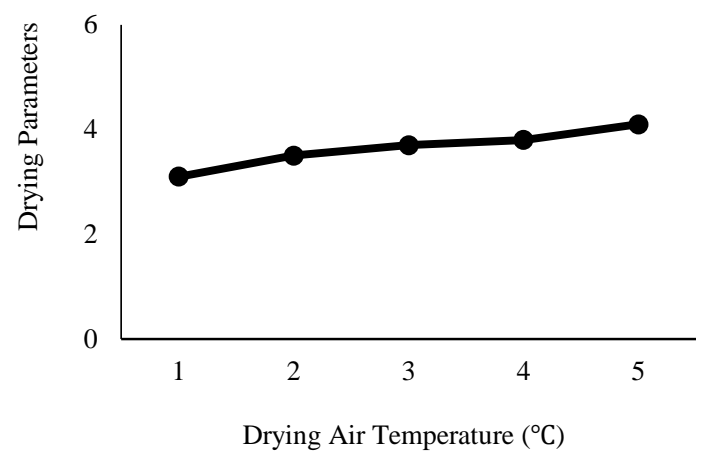

Figure 4. Graph of the relationship between drying air temperature and drying parameters $\left(\mathrm{J}_{\mathrm{p}}\right)$

The higher the temperature used, the better the drying process because of the decomposition process that can release water content. This is caused by the drying temperature which plays a role in the evaporation of water contained in the material, if the drying temperature is greater, the water that can be evaporated will be more and the water content in the product will be smaller [11].

The higher the drying temperature, the greater the temperature difference between the heating medium and the material, the faster the heat transfer occurs so that more water is evaporated and the drying speed is faster. The effect of temperature on water content will be seen with a significant decrease for each increase in drying temperature [12].

The more high-temperature drying air, the faster the removal of steam from the material so that the drying process is faster [13]. Not only with the spray dryer method, but this also applies to other thermal methods [14].

\section{Preferred Test Data Retrieval Technique (Hedonic Test)}

The following is a data table and graph of the organoleptic test for instant soy milk including:

a. Organoleptic data on the taste of instant soy milk b. Organoleptic data on the aroma of instant soy milk

c. Organoleptic data on the color of instant soy milk

d. The test results of the importance of instant soy milk

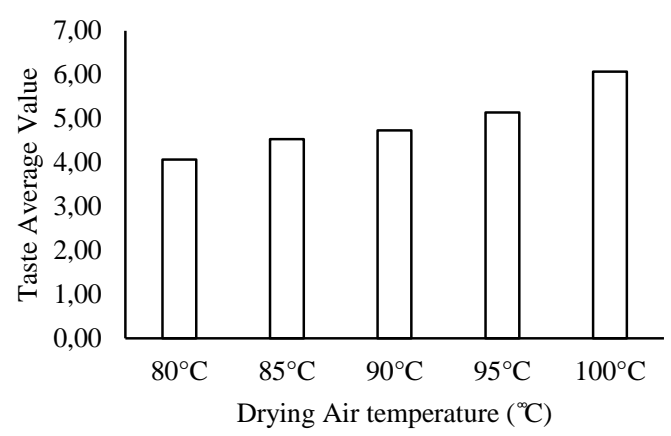

Figure 5. Organoleptic Chart of Instant Soy Milk Flavor

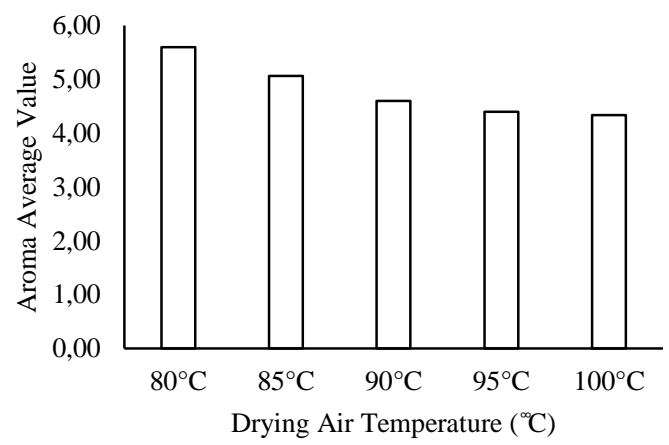

Figure 6. Organoleptic Graph of the Aroma of Instant Soy Milk

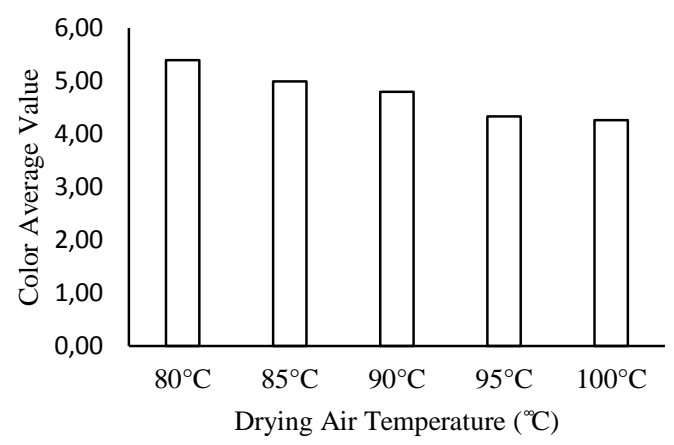

Figure 7. Organoleptic Chart of Instant Soy Milk Color

The higher the temperature used, the higher the average value of the milk taste obtained. However, it is inversely proportional to the value of the aroma and 
color produced. This is due to the decomposition of an excess product.

\section{Conclusion}

Based on the research that has been done, it can be concluded that increasing the drying air temperature of $80^{\circ} \mathrm{C}$ to $100^{\circ} \mathrm{C}$ causes a decrease in the need for drying air, namely $27.323 \mathrm{~kg}$ dry air / hour to $9.840 \mathrm{~kg}$ dry air / hour, the drying time of the material is getting shorter, namely 1 hour 10 minutes to 1 hour, the increase in thermal efficiency was $81.9 \%$ to $84.3 \%$, and the increase in product weight leaving the drying chamber was 3.1 grams to 4.1 grams.

For better production results, an organoleptic test is needed to test the quality of instant soy milk products (taste, color, and aroma) specifically. The results of the questionnaire showed that the panelists tended to rank taste first $(65 \%)$, aroma second $(61.25 \%)$, color third $(47.5 \%)$.

\section{References}

[1] S. Rohmani, A. Yugatama, and F. Prihapsara, "Inovasi Minuman Sehat Berbahan Kedelai dalam Upaya Pemberdayaan Masyarakat melalui Wirausaha di Kabupaten Sukoharjo ( Innovations Healthy Drinks in Source of Soybean in Community Empowerment through Entrepreneurship in Sukoharjo District )," Agrokreatif,Jurnal Ilm. Pengabdi. Kpd. Masy., vol. 4, no. 1, pp. 68-74, 2018.

[2] N. Prayuga, T. Hanum, and A. Rangga, "Evaluasi Usaha Susu Kedelai Nur Prayuga et al Nur Prayuga et al," vol. 19, no. 1, pp. 7083, 2014.

[3] M. Fathurohman, A. Y. Aprillia, A. T. K. Pratita, and V. F. Tenderly, "Diversifikasi Produksi Susu Kedelai Berbasis Mikroalga Autotrofik Guna Meningkatkan Indeks Nutraseutikal," J. Apl. Teknol. Pangan, vol. 9, no. 2, pp. 70-76, 2020, doi: 10.17728/jatp.6150.
[4] R. Rosniati, "Pengembangan Minuman Instan Cokelat- Kedelai Sebagai Minuman Kesehatan," J. Ind. Has. Perkeb., vol. 11, no. 1, p. 33, 2016, doi: 10.33104/jihp.v11i1.3408.

[5] A. Riansyah, A. Supriadi, and R. Nopianti, "Pengaruh Perbedaan Suhu dan Waktu Pengeringan terhadap Karakteristik Ikan Asin Sepat Siam (Trichogaster Pectoralis) dengan menggunakan Oven," pp. 53-68, 1384.

[6] H. Vistanty, "pengeringan Pasta Susu Kedelai Menggunakan Pengering Unggun Terfluidakan Partikel Inert," pp. 1-50, 2010.

[7] H. Dewi Astuti and W. D. Andang Arif, "Pengaruh Konsentrasi Susu Skim Dan Waktu Fermentasi Terhadap Hasil Pembuatan Soyghurt," Envirotek J. Ilm. Tek. Lingkung., vol. 2, no. 1, pp. 48-58, 2009.

[8] P. Seyadi, N. Y. Yoga, and I. Fadillah, "Proses Perancangan Manufaktur Mesin Pengering Larutan dengan Metode Spray Dryer Type Up draft," vol. 1, pp. 69-76, 2020.

[9] Jamaluddin, Perpindahan Panas dan Massa pada Penyangraian dan Penggorengan Bahan Pangan, 2018th ed. Badan Penerbit UNM.

[10] Zuhra, Sofyana, and C. Erlina, "Pengaruh Kondisi Operasi Alat Pengering Semprot Terhadap Kualitas Susu Bubuk Jagung," J. Rekayasa Kim. Lingkung., vol. 9, no. 1, pp. 3644, 2012.

[11] L. Kumalla, S. H. S, and M. Bagus Hermanto, "Uji Performansi Pengering Semprot Tipe Buchi B-290 Pada Proses Pembuatan Tepung Santan," J. Bioproses Komod. Trop., vol. 1, no. 1, pp. 44-53, 2013.

[12] R. T. Dwika and J. P. Soedarto, "Pengaruh dan Laju Alir Udara Pengering pada Pengeringan Karaginan menggunakan Teknologi Spray Dryer," vol. 1, no. 1, pp. 298- 
304, 2012.

[13] A. Dewi and L. Satibi, "Kajian Pengaruh Temperatur Pengeringan Semprot (Spray Dryer) Terhadap Kadar Air Santan Kelapa Bubuk (Coconut Milk Powder)," J. Konversi Univ. Muhammadiyah Jakarta, vol. 4, no. 1, p. 108362, 2015, doi: 10.24853/konversi.4.1.

[14] A. Abidin, C. W. Purnomo, and R. B. Cahyono, "Hydro-char Production from Press-mud Wastes of The Sugarcane Industry by Hydrothermal Treatment with Natural Zeolite Addition," vol. 020049, 2018, doi: 10.1063/1.5065009.

[15] Budiyanto, E., Yuono, L. D., \& Farindra, A. (2019). Upaya Peningkatan Kualitas dan Kapasitas Produksi Mesin Pengupas Kulit Kopi Kering. Turbo: Jurnal Program Studi Teknik Mesin, 8(1). 